\title{
System wsparcia osób z niepełnosprawnościami i ich rodzin w Polsce
}

Moment pojawienia się $\mathrm{w}$ rodzinie osoby $\mathrm{z}$ niepełnosprawnością zawsze niesie ze sobą bardzo wiele emocji. Jest to sytuacja trudna, której charakterystycznymi cechami są: poczucie lęku o zdrowie i rozwój dziecka, zagubienie wynikające z niedostatku informacji o jego niepełnosprawności, smutek, uczucie wstydu, osamotnienie i brak akceptacji społecznej oraz bezradność i zmęczenie, wynikające z nieustannej mobilizacji sił i zwiększenia się liczby obowiązków rodzinnych ${ }^{1}$. Ogromne znaczenie w podniesieniu jakości życia osób z niepełnosprawnościami i ich rodzin ma właściwa znajomość i wykorzystanie funkcjonującego w Polsce systemu wsparcia, który jest tworzony i rozbudowywany od ponad 20 lat.

Pierwszy akt prawny regulujący funkcjonowanie tej grupy obywateli został uchwalony przez Sejm Rzeczypospolitej Polskiej 9 maja 1991 roku - była to Ustawa o zatrudnieniu i rehabilitacji zawodowej osób niepełnosprawnych.

Sama ustawa, jak i cały - rozbudowany dzisiaj - system wsparcia przez wszystkie te lata ewoluuje, coraz lepiej wpisując się w stale zmieniające się potrzeby populacji osób z niepełnosprawnościami w Polsce.

Por. M. Kościółek, Lęk rodziców wychowujących dziecko z niepełnosprawnościa, [w:] Dziecko a świat dorostych, red. M. Duda, B. Gulla, Kraków 2007, s. 75-81. 
Liczebność populacji stanowi o skali potrzeb w zakresie wsparcia w dążeniu do uzyskania jak najwyższej jakości życia, możliwości wykonywania zadań życiowych i realizacji ról społecznych przez osoby z niepełnosprawnościami. Aby scharakteryzować, a zarazem pokazać ogromną różnorodność populacji osób z niepełnosprawnościami w Polsce, poniżej zaprezentowano wybrane dane statystyczne dotyczące tej właśnie grupy osób. Jedynym badaniem, którego wyniki pozwalają ustalić liczbę osób niepełnosprawnych oraz umożliwiają szczegółową charakterystykę tej grupy ludności, są spisy powszechne ludności. Polska jest jednym z nielicznych krajów, w których badanie zjawiska niepełnosprawności podczas spisów powszechnych stało się już tradycją². Według definicji Głównego Urzędu Statystycznego osobą niepełnosprawną jest osoba, która posiada odpowiednie orzeczenie wydane przez organ do tego uprawniony lub osoba, która takiego orzeczenia nie posiada, lecz odczuwa ograniczenie sprawności w wykonywaniu czynności podstawowych dla swojego wieku (zabawa, nauka, praca, samoobsługa). Na podstawie Narodowego Spisu Powszechnego (NSP) przeprowadzonego w Polsce w 2002 roku, stwierdzono, że w roku przeprowadzenia badania liczba osób niepełnosprawnych w Polsce wynosiła 5456,7 tys., co stanowiło 14,3\% ogółu ludności kraju. Oznacza to, że co siódmy mieszkaniec Polski był osobą niepełnosprawną. Porównując dostępne dane z lat 1978 i 1988, stwierdza się znaczne zwiększenie liczby osób niepełnosprawnych: w 1978 roku - co czternasty, a w 1988 roku - co dziesiąty mieszkaniec Polski był osobą niepełnosprawną. Na przestrzeni niespełna 25 lat (1978-2002) liczba niepełnosprawnych mieszkańców Polski zwiększyła się o ponad $100 \%$.

2 Por. Główny Urząd Statystyczny, Raport z wyników. Narodowy Spis Ludności i Mieszkań 2011, Warszawa 2012, s. 63, www.stat.gov.pl (21.10.2014). 
Zgodnie z zapisami ustawy z 4 marca 2010 roku o narodowym spisie powszechnym ludności i mieszkań udzielanie odpowiedzi na pytania dotyczące niepełnosprawności odbywało się w 2011 roku na zasadzie dobrowolności - ze względu na specyfikę i wrażliwość tematu. Na pytania odpowiadały osoby dorosłe, które wyraziły na to zgodę, natomiast na temat dzieci informacji udzielali rodzice lub opiekunowie. Wyniki spisu ludności 2011 roku pokazały wstępnie, że liczba osób, które zadeklarowały ograniczenie zdolności do wykonywania zwykłych czynności podstawowych dla swojego wieku i/lub posiadały ważne orzeczenie kwalifikujące je do zaliczenia do zbiorowości osób niepełnosprawnych wynosiła 4697,5 tys., co stanowiło 12,2\% ludności kraju, wobec 14,3\% w 2002 roku. Należy w tym miejscu podkreślić, że w związku z dobrowolnym charakterem pytań dotyczących niepełnosprawności blisko 1,5 mln respondentów odmówiło udzielenia odpowiedzi. Można przypuszczać, że w tej zbiorowości znajdują się osoby niepełnosprawne, które mogą posiadać udokumentowane orzeczenie, jednak nie chciały udzielić odpowiedzi na pytania zawarte w formularzu w części dotyczącej niepełnosprawności. Również braki danych mogą rzutować na uzyskaną w spisie strukturę osób niepełnosprawnych.

Bardzo liczną grupą ludności, o której nie zebrano bardziej szczegółowych danych (również w innych obszarach tematycznych) są przede wszystkim osoby przebywające za granicą 12 miesięcy lub dłużej. W świetle powyższych wyjaśnień należy przyjąć, że ogólne liczby osób niepełnosprawnych mężczyzn i kobiet, w miastach i na wsi, uzyskane wstępnie z wyników spisu 2011 - są niedoszacowane.

W konsekwencji zaniżone są także odsetki osób niepełnosprawnych w relacji do ogólnej liczby ludności ${ }^{3}$.

3 Por. tamże. 
Wykres 1. Porównanie wzrostu liczebności populacji osób niepełnosprawnych w latach $1978-1988-2002-2011$ (dane w tysiącach).

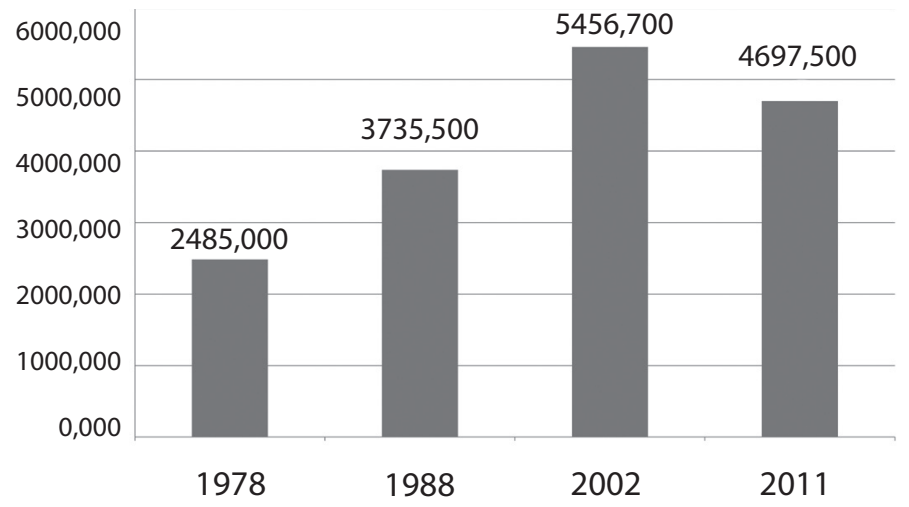

Źródło: Główny Urząd Statystyczny, Raport z wyników Narodowego Spisu Powszechnego Ludności i Mieszkań 2002, Warszawa 2003; Główny Urząd Statystyczny, Raport z wyników. Narodowy Spis Ludności i Mieszkań 2011, Warszawa 2012.

\section{Przyczyny niepełnosprawności}

W analizowanym okresie najczęstszą przyczynę niepełnosprawności ${ }^{4}$ stanowiły uszkodzenia i choroby narządów ruchu (55,8\%), schorzenia układu krążenia (49,6\%), scho-

4 Na podstawie wyników Europejskiego Ankietowego Badania Zdrowia przeprowadzonego przez GUS w 2009 roku; poszczególne udziały nie sumują się do $100 \%$, ponieważ dana osoba mogła mieć kilka rodzajów schorzeń powodujących niepełnosprawność. W porównaniu z wynikami Badania Stanu Zdrowia Ludności 2004 wzrósł udział osób, dla których najczęstszą przyczynę niepełnosprawności stanowiły uszkodzenia i choroby narządów ruchu (z 46,1\% do $55,8 \%$ ) oraz schorzenia układu krążenia (z 48,5\% do 49,6\%), a także schorzenia neurologiczne (z $29 \%$ do $33 \%$ ) i psychiczne (z 7,9\% do $10,1 \%$ ), jak też upośledzenie umysłowe (z 2,5\% do 4,0\%). Obniżył się natomiast odsetek osób, dla których główną przyczyną niepełnosprawności były choroby narządu wzroku (z 29,5\% do 27,3\%) i słuchu (z 13,9\% do 13,7\%). 
rzenia neurologiczne (33\%) oraz uszkodzenia i choroby wzroku $(27,3 \%)^{5}$.

Niższy natomiast jest procentowy udział w zbiorowości osób niepełnosprawnych osób z uszkodzeniami i chorobami narządu słuchu (13,7\%), z chorobami psychicznymi $(10,1 \%)$ i upośledzeniem umysłowym $(4,0 \%)$. Warto jednak podkreślić, iż odsetki te przekładają się na tysiące osób niepełnosprawnych o obniżonej sprawności w codziennym funkcjonowaniu, które wymagają szczególnego wsparcia w edukacji, na rynku pracy i w życiu codziennym.

Najczęstszą przyczyną niepełnosprawności osób w wieku produkcyjnym były schorzenia i dysfunkcje narządu ruchu, a w następnej kolejności: schorzenia układu krążenia i neurologiczne oraz choroby narządu wzroku6 . Wśród osób niepełnosprawnych w starszym wieku ${ }^{7}$ najczęstszą przyczyną niepełnosprawności były schorzenia ukła-

5 Na podstawie wyników Europejskiego Ankietowego Badania Zdrowia przeprowadzonego przez GUS w 2009 roku; poszczególne udziały nie sumują się do $100 \%$, ponieważ dana osoba mogła mieć kilka rodzajów schorzeń powodujących niepełnosprawność.

6 W przypadku osób w wieku produkcyjnym w 2009 roku w porównaniu z 2004 rokiem znacząco wzrósł odsetek osób, dla których najczęstszą przyczynę niepełnosprawności stanowiły schorzenia i dysfunkcje narządu ruchu (z 41,9\% do 48,2\%) i schorzenia neurologiczne (z $30,9 \%$ do $32,7 \%$ ), oraz schorzenia psychiczne (z 11,3\% do 14,8\%) i upośledzenie umysłowe (z 4,1\% do 7,2\%). Obniżył się natomiast udział osób, dla których były nią schorzenia układu krążenia (z 37,1\% do $32,9 \%$ ) oraz choroby narządu wzroku (z 22,4\% do 20,0\%) i słuchu (z $8,3 \%$ do $6,2 \%$ ).

7 W wieku 60 lat i więcej. Wśród osób starszych w 2009 roku w porównaniu z 2004 rokiem znacząco wzrósł odsetek osób, dla których najczęstszą przyczynę niepełnosprawności stanowiły schorzenia układu krążenia (z 59,7\% do 63,7\%, które wciąż wysuwają się na pierwsze miejsce), następnie narządów ruchu (z 50,2\% do 62,2\%) oraz schorzenia neurologiczne (z 27,2\% do 33,3\%) i psychiczne (z 4,4\% do 6,1\%), natomiast obniżył się udział osób, dla których najczęstszą przyczynę niepełnosprawności stanowiły choroby narządu wzroku (z 36,5\% do $33,5 \%)$. Poszczególne udziały mogą nie sumować się do 100\%, ponieważ dana osoba mogła mieć kilka rodzajów schorzeń powodujących niepełnosprawność. 
du krążenia (63,7\%), następnie narządów ruchu (62,2\%), wzroku i neurologiczne. Schorzenia psychiczne i upośledzenia umysłowe częstsze są w grupie osób niepełnosprawnych w wieku produkcyjnym niż w grupie starszych osób niepełnosprawnych.

Wykres 2: Struktura osób niepełnosprawnych w wieku 16 lat i więcej według schorzeń powodujących niepełnosprawność w 2009 roku

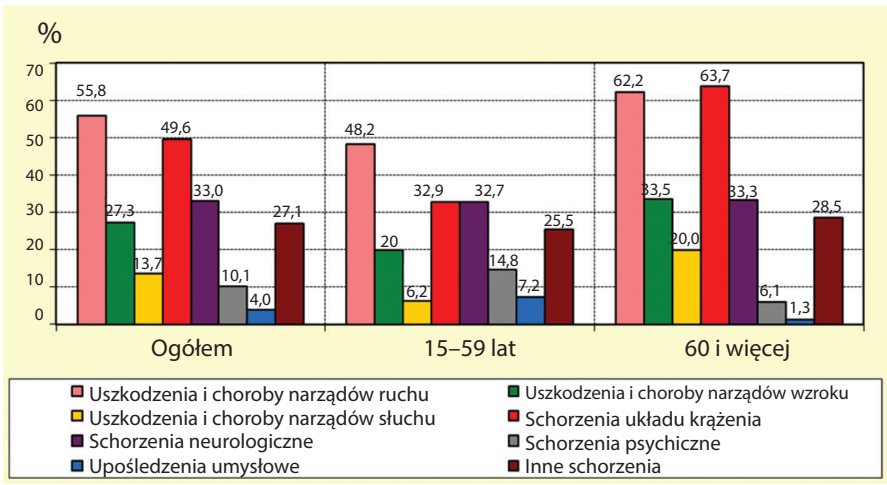

Źródło: Dane statystyczne dotyczące sytuacji osób niepełnosprawnych $\mathrm{z}$ uwzględnieniem istotnych zmian i tendencji na przestrzeni ostatnich lat, http://www.niepelnosprawni.gov.pl/download/(15iane7hW5Wxx6KZcIDWz5Wzip-nj9GhbI-XntyyU6Dfjpiin5iZnuayV5mwdtvgqtPHxt3ZgNTpw8rGpMfL09jkj9TpxNrIrczfxtvXj8bVxNrhm9Ha1e3dj87Vw9vbl9LUzNbggNHXyJbLpcGIvA)/files/niepelnosprawnosc_w_liczbach/ rynek_pracy/sytuacja_osob_niepelnosprawnych_na_przestrzeni_ostatnich_ lat.doc. (15.10.2014).

Kolejnym determinantem warunkującym często potrzebę korzystania z systemu wsparcia jest poziom wykształcenia osób z niepełnosprawnościami. Osoby niepełnosprawne prawnie są znacznie gorzej wykształcone niż osoby sprawne, jednak w ostatnich latach następuje stopniowy wzrost poziomu wykształcenia na poziomie średnim i wyższym wśród tej grupy osób. Udział osób niepełnosprawnych w wieku 16 lat i więcej z co najmniej średnim poziomem wykształcenia wzrósł z 31,8\% w 2008 
roku, 32,1\% w 2009 roku, 33,7\% w 2010 roku - do 34,4\% w 2011 roku. Udział osób niepełnosprawnych w wieku produkcyjnym z co najmniej średnim poziomem wykształcenia wzrósł do 34,1\% w 2011 roku (tak samo jak w roku poprzednim, zaś o 1,3 pkt. proc. więcej niż w roku 2009 kiedy wynosił $32,8 \%$ i o 0,7 pkt. proc. więcej niż w 2008 roku).

Wykres 3. Struktura osób niepełnosprawnych prawnie w wieku produkcyjnym według poziomu wykształcenia w latach 2008-2011

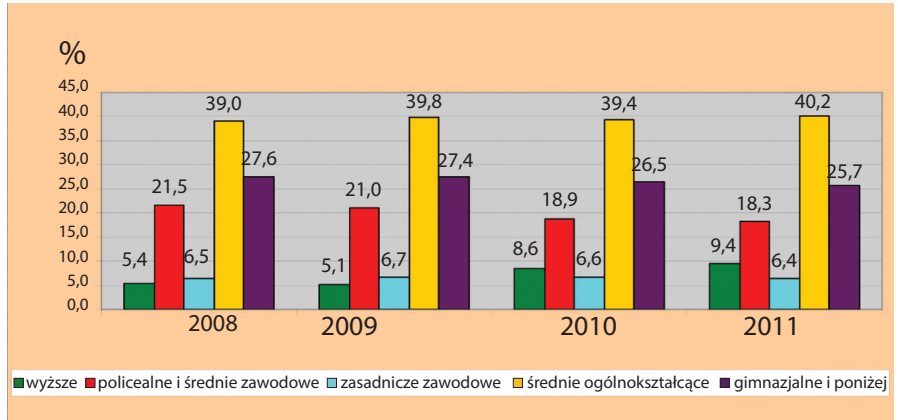

Źródło: Dane statystyczne dotyczące sytuacji osób niepełnosprawnych $\mathrm{z}$ uwzględnieniem istotnych zmian i tendencji na przestrzeni ostatnich lat, http://www.niepelnosprawni.gov.pl/download/(15iane7hW5Wxx6KZcIDWz5Wzip-nj9GhbI-XntyyU6Dfjpiin5iZnuayV5mwdtvgqtPHxt3ZgNTpw8rGpMfL09jkj9TpxNrIrczfxtvXj8bVxNrhm9Ha1e3dj87Vw9vbl9LUzNbggNHXyJbLpcGInvA)/files/niepelnosprawnosc_w_liczbach/ rynek_pracy/sytuacja_osob_niepelnosprawnych_na_przestrzeni_ostatnich_ lat.doc. (15.10.2014).

Warto zwrócić uwagę na fakt, że od 2007 roku odnotowuje się znaczny wzrost współczynnika aktywności zawodowej i wskaźnika zatrudnienia osób niepełnosprawnych, szczególnie w wieku aktywności zawodowej. Posiadane wykształcenie różnicuje aktywność zawodową osób niepełnosprawnych - istnieje powiązanie: im wyższy poziom wykształcenia posiadanego przez osoby niepełnosprawne, tym wyższy współczynnik aktywności zawodowej tych osób, jak też wskaźnik zatrudnienia. Najwyższą aktywno- 
ścią zawodową cechują się osoby z wyższym i średnim poziomem wykształcenia.

Wykres 4. Porównanie wskaźnika aktywności zawodowej osób z niepełnosprawnościami ze względu na poziom wykształcenia, w wieku 16 lat i więcej w latach $2008-2011$

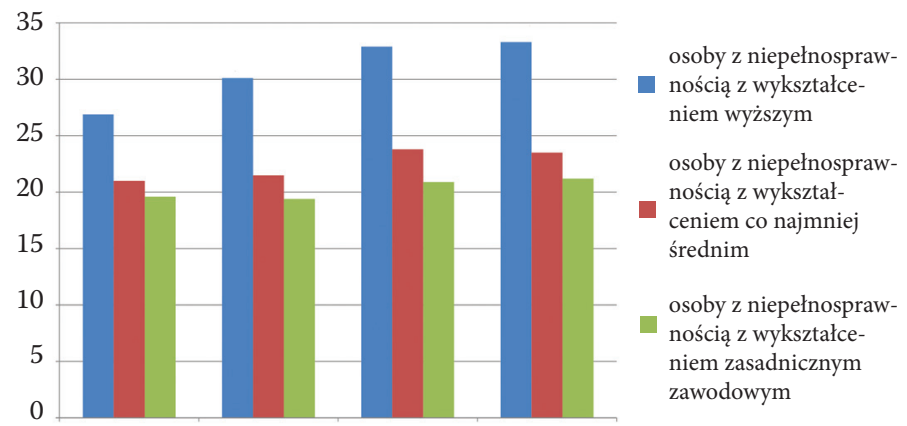

Źródło: Autorstwo własne, na podstawie: Główny Urząd Statystyczny, Raport z wyników. Narodowy Spis Ludności i Mieszkań 2011, Warszawa 2012.

\section{System wsparcia}

Pojęcie wsparcia cechuje się wieloznacznością, a próby jego doprecyzowania przyjmują zwykle postać definiowania poprzez wskazanie na jego strukturę i funkcje. Problematyka wsparcia społecznego obejmuje wszystkie etapy życia człowieka, który znajduje się w specyficznych, trudnych, ale i codziennych sytuacjach wymagających wspierającej obecności innych osób. Zapotrzebowanie na nie wzrasta w wówczas, gdy mobilizacja indywidualnych zasobów jednostki jest niewystarczająca i nieskuteczna ${ }^{8}$. Aleksandra Maciarz definiuje wsparcie społeczne jako: „różnorodną pomoc, dostępną w jej środowisku świadczoną przez różne instytucje, stowarzyszenia społeczne oraz osoby i inne ro-

8 Por. W. Janocha, Rodzina z osobq niepetnosprawna w spotecznym systemie wsparcia, Kielce 2009. 
dziny, z którymi pozostaje w kontaktach i więzi" ${ }^{\prime 9}$. Podobną definicję przytacza Mieczysław Radochoński: „[...] Wsparcie społeczne, to różnorodna pomoc dostępna danej rodzinie poprzez więzy społeczne $\mathrm{z}$ innymi jednostkami, grupami, instytucjami" ${ }^{10}$. Wspomaganie społeczne rodziny dziecka niepełnosprawnego jest związane z różnymi dziedzinami życia rodziny i dotyczy - wg Radochońskiego czterech podstawowych systemów:

1. systemu wsparcia ekonomicznego (obejmującego głównie pomoc finansową),

2. systemu usług (obejmującego pomoc w opiece nad dzieckiem, robieniu zakupów itp.),

3. systemu wsparcia społecznego (obejmującego między innymi składanie wizyt, wychodzenie na spacer, obchodzenie uroczystości itp.),

4. systemu wsparcia emocjonalnego (odnoszącego się do przeżyć uczuciowych doznawanych w relacjach interpersonalnych) ${ }^{11}$.

Z kolei Zofia Kawczyńska-Butrym źródła wsparcia osobom niepełnosprawnym i ich rodzinom dzieli na:

1. pierwotne - rodzina, sąsiedzi, przyjaciele;

2. wtórne - takie jak:

- instytucje rządowe i pozarządowe, na przykład służba zdrowia, fundacje, które zabezpieczają warunki opieki, życia i rozwoju,

- specjalne programy pomocy chorym i ich rodzinom, hospicja itp.,

- grupy samopomocy, stowarzyszenia osób chorych, ich rodzin oraz wolontariusze ${ }^{12}$.

9 A. Maciarz, Wspomaganie rodziny $w$ wychowaniu $i$ rehabilitacji dzieci, „Problemy Opiekuńczo-Wychowawcze” 1992 nr 5/6, s. 254-257.

10 M. Radochoński, Rola rodziny w zmaganiu się ze stresem wywołanym chorobq somatyczna, „Problemy Rodziny” 1991 nr 6, s. 10.

11 Por. tamże.

12 Por. Z. Kawczyńska-Butrym, Elementy socjologii dla pielęgniarek, Lublin 2000, za: K. Hebel, L. Bieniaszewski, Wsparcie społeczne i po- 
Każde z tych źródeł może być skierowane na udzielanie różnego rodzaju wsparcia. Jednak najczęściej i najbardziej pożądane jest udzielanie równolegle kilku rodzajów wsparcia (np. emocjonalne i rzeczowe, emocjonalne i w usługach) przez różne źródła. Taka sieć wsparcia społecznego obniża ryzyko powikłań zdrowotnych, psychologicznych i fizycznych, a nawet zmniejsza ryzyko zgonu ${ }^{13}$.

Wsparcie „powinno być rozumiane jako specyficzny sposób pomagania, odwołujący się przede wszystkim do zasobów osoby wspomaganej, stanowiący zachęcenie i motywowanie człowieka do uruchamiania działań samopomocowych"14.

Osoby $\mathrm{z}$ niepełnosprawnościami często korzystają z systemu wsparcia. Ograniczenia i potrzeby wynikające z niepełnej sprawności organizmu w różnych obszarach powodują trudności w samodzielnym funkcjonowaniu. W polskim systemie prawnym istnieje ustawowy podział na wsparcie kierowane wprost do indywidualnych osób niepełnosprawnych oraz do ich rodzin. Kierując się podziałem zaproponowanym przez Radochońskiego, jako pierwszy zostanie omówiony system wsparcia finansowego. Istotnym warunkiem korzystania $\mathrm{z}$ instrumentów wsparcia dedykowanych osobom niepełnosprawnym jest posiadanie orzeczenia o niepełnosprawności. Tylko osoby posiadające prawne stwierdzenie niepełnosprawności mogą zatem otrzymywać wsparcie finansowe pochodzące ze środków publicznych. Dla celów orzekania o niepełnosprawności ustawodawca powołał zespoły orzekające o niepełnosprawności:

1) powiatowe zespoły do spraw orzekania o niepełnosprawności - jako pierwsza instancja;

moc instytucjonalna dla osób niepetnosprawnych po udarze mózgu, „Forum Medycyny Rodzinnej” 2008 t. 2 nr 1, s. 77.

13 Por. tamże, s. 77-78.

14 J. Mellibruda, Ja - ty - my. Psychologiczne możliwości ulepszania kontaktów międzyludzkich, Warszawa 1986, s. 238. 
2) wojewódzkie zespoły do spraw orzekania o niepełnosprawności - jako druga instancja.

W orzeczeniu powiatowego zespołu, poza ustaleniem niepełnosprawności lub stopnia niepełnosprawności, powinny być zawarte wskazania dotyczące w szczególności:

„1) odpowiedniego zatrudnienia uwzględniającego psychofizyczne możliwości danej osoby;

2) szkolenia, w tym specjalistycznego;

3) zatrudnienia w zakładzie aktywności zawodowej;

4) uczestnictwa w terapii zajęciowej;

5) konieczności zaopatrzenia w przedmioty ortopedyczne, środki pomocnicze oraz pomoce techniczne, ułatwiające funkcjonowanie danej osoby;

6) korzystania z systemu środowiskowego wsparcia w samodzielnej egzystencji, przez co rozumie się korzystanie z usług socjalnych, opiekuńczych, terapeutycznych i rehabilitacyjnych świadczonych przez sieć instytucji pomocy społecznej, organizacje pozarządowe oraz inne placówki;

7) konieczności stałej lub długotrwałej opieki lub pomocy innej osoby w związku ze znacznie ograniczoną możliwością samodzielnej egzystencji;

8) konieczności stałego współudziału na co dzień opiekuna dziecka w procesie jego leczenia, rehabilitacji i edukacji;

9) spełniania przez osobę niepełnosprawną przesłanek określonych w art. 8 ust. 3a, pkt 1 i 2 ustawy z dnia 20 czerwca 1997 r. - Prawo o ruchu drogowym (Dz.U. z 2012 r., poz. 1137, z późn. zm. 4)"15.

Osoby niepełnosprawne mogą korzystać z wszystkich wymienionych powyżej instrumentów określonych w ustawie z 27 sierpnia 1997 roku o rehabilitacji zawodowej i spo-

15 Ustawa z dnia 27 sierpnia 1997 r. o rehabilitacji zawodowej i społecznej oraz zatrudnianiu osób niepełnosprawnych (Dz.U. z 1997 r. Nr 123, poz. 776 , art. $6 \mathrm{~b}, \mathrm{z}$ późn. zm.). 
łecznej oraz zatrudnianiu osób niepełnosprawnych ${ }^{16}$, do których zaliczyć należy przede wszystkim:

- Dofinansowanie kosztów uczestnictwa osób niepełnosprawnych $i$ ich opiekunów w turnusach rehabilitacyjnych. Uczestnictwo w turnusie rehabilitacyjnym, według ustawy o rehabilitacji, wspomaga proces rehabilitacji zawodowej i społecznej osób niepełnosprawnych. Turnus oznacza zorganizowaną formę aktywnej rehabilitacji połączonej z elementami wypoczynku, której celem jest ogólna poprawa psychofizycznej sprawności oraz rozwijanie umiejętności społecznych uczestników, między innymi przez nawiązywanie i rozwijanie kontaktów społecznych, realizację i rozwijanie zainteresowań, a także przez udział w innych zajęciach przewidzianych programem turnusu. Turnusy organizuje się wyłącznie na terenie kraju, w grupach zorganizowanych liczących nie mniej niż 20 uczestników, w formie stacjonarnej i niestacjonarnej. Osobie niepełnosprawnej ze znacznym lub umiarkowanym stopniem niepełnosprawności albo posiadającej orzeczenie równoważne oraz osobie niepełnosprawnej w wieku do 16 lat może być przyznane dofinansowanie pobytu opiekuna (przy spełnieniu wymaganych kryteriów).

- Dofinansowanie zaopatrzenia w sprzęt rehabilitacyjny, przedmioty ortopedyczne i środki pomocnicze. Sprzęt rehabilitacyjny jest to sprzęt niezbędny do rehabilitacji ruchowej lub innej, zaleconej przez lekarza w warunkach domowych, a który nie jest objęty ubezpieczeniem zdrowotnym. Przepisy prawa nie dookreślają, na jaki sprzęt PCPR może udzielić dofinansowania. Przedmioty ortopedyczne i środki pomocnicze są 
skatalogowane, a katalog jest załącznikiem do stosownego rozporządzenia Ministra Zdrowia ${ }^{17}$. W rozporządzeniu określone są limity finansowania każdego przedmiotu $\mathrm{w}$ ramach ubezpieczenia, dlatego procentowe wskaźniki dofinansowań ze środków PFRON odnoszą się wprost do tych limitów. Podstawowym warunkiem uzyskania dofinansowania zaopatrzenia w sprzęt rehabilitacyjny, przedmioty ortopedyczne i środki pomocnicze jest posiadanie odpowiedniego dokumentu potwierdzającego niepełnosprawność oraz spełnienie kryterium dochodowego. Wysokość dofinansowania wynosi:

- w przypadku zaopatrzenia w sprzęt rehabilitacyjny - do 60\% jego kosztów, nie więcej jednak niż do wysokości pięciokrotnego przeciętnego wynagrodzenia,

- w przypadku zaopatrzenia w przedmioty ortopedyczne i środki pomocnicze - do 100\% udziału własnego osoby niepełnosprawnej w wyznaczonym przez Narodowy Fundusz Zdrowia limicie ceny, ustalonym na podstawie odrębnych przepisów, jeżeli taki udział jest wymagany, do 150\% sumy kwoty limitu, o którym mowa wyżej, wyznaczonego przez Narodowy Fundusz Zdrowia oraz wymaganego udziału własnego osoby niepełnosprawnej w zakupie tych przedmiotów i środków pomocniczych, jeżeli cena zakupu jest wyższa niż ustalony limit.

- Dofinansowanie likwidacji barier architektonicznych, w komunikowaniu się i technicznych, w związku z indywidualnymi potrzebami osób niepełnosprawnych - o dofinansowanie likwidacji barier mogą ubiegać się:

17 Rozporządzenie Ministra Zdrowia z dnia 6 grudnia 2013 r. w sprawie wykazu wyrobów medycznych wydawanych na zlecenie (Dz.U. z 2013, poz. 1565). 
- w przypadku barier architektonicznych - osoby niepełnosprawne, które mają trudności w poruszaniu się, jeżeli są właścicielami nieruchomości lub użytkownikami wieczystymi nieruchomości albo posiadają zgodę właściciela lokalu lub budynku mieszkalnego, w którym stale zamieszkują,

- w przypadku barier w komunikowaniu się i technicznych - osoby niepełnosprawne, jeżeli jest to uzasadnione potrzebami wynikającymi z niepełnosprawności.

Przyznane dofinansowanie ma na celu umożliwienie lub w znacznym stopniu ułatwienie osobie niepełnosprawnej wykonywania podstawowych, codziennych czynności lub kontaktów z otoczeniem.

Wyżej wymienione instrumenty wsparcia są finansowane ze środków Państwowego Funduszu Rehabilitacji Osób Niepełnosprawnych, który deleguje realizację zadań do jednostek samorządu terytorialnego - powyższe formy wsparcia indywidualnych osób niepełnosprawnych realizowane są przez starostwa powiatowe za pośrednictwem Powiatowych Centrów Pomocy Rodzinie (PCPR) lub Miejskich Ośrodków Pomocy Społecznej (MOPS) - w miastach na prawach powiatu. Wnioski o dofinansowanie poszczególnych zadań (właściwe dla każdego starostwa) należy składać w PCPR. Warunkiem otrzymania i wydatkowania środków finansowych jest decyzja przyznająca środki finansowe lub podpisanie umowy ze starostą, która szczegółowo określa wysokość i warunki dofinansowania (w zależności od rodzaju pomocy).

Odrębny system wsparcia finansowego osób niepełnosprawnych i ich rodzin wynika z przepisów ustawy z dnia 28 listopada 2003 roku o świadczeniach rodzinnych ${ }^{18}$, zwanej dalej „ustawą o świadczeniach rodzinnych”. Rozwiązania

18 Ustawa o świadczeniach rodzinnych (Dz.U. z 2006 r. Nr 139, poz. 992, z późn. zm.). 
określone $\mathrm{w}$ tej ustawie skierowane są m.in. do rodzin i opiekunów osób niepełnosprawnych. Podstawowym instrumentem wspierającym rodziny i opiekunów osób niepełnosprawnych są świadczenia opiekuńcze - świadczenie pielęgnacyjne i specjalny zasiłek opiekuńczy:

- Świadczenie pielęgnacyjne wypłacane jest z tytułu niepodejmowania lub rezygnacji z zatrudnienia lub innej pracy zarobkowej w celu sprawowania opieki nad osobą legitymującą się orzeczeniem o znacznym stopniu niepełnosprawności albo orzeczeniem o niepełnosprawności łącznie ze wskazaniami: konieczności stałej lub długotrwałej opieki lub pomocy innej osoby w związku ze znacznie ograniczoną możliwością samodzielnej egzystencji oraz konieczności stałego współudziału na co dzień opiekuna dziecka w procesie jego leczenia, rehabilitacji i edukacji.

- Specjalny zasiłek opiekuńczy przysługuje osobom, na których zgodnie z przepisami ustawy z dnia 25 lutego 1964 r. - Kodeks rodzinny i opiekuńczy ciąży obowiązek alimentacyjny, po spełnieniu przesłanki rezygnacji z zatrudnienia lub innej pracy zarobkowej w związku z koniecznością sprawowania stałej opieki nad niepełnosprawnym członkiem rodziny.

- Jednorazowa zapomoga z tytułu urodzenia się dziecka. Świadczenia te są finansowane w formie dotacji celowej z budżetu państwa. Aby jednak uzyskać do nich prawo, trzeba spełnić warunki określone w ustawie o świadczeniach rodzinnych. Wypłata świadczeń rodzinnych ma na celu wspomożenie rodzin wychowujących dzieci lub opiekujących się osobami niepełnosprawnymi, zwłaszcza gdy znajdują się one w trudnej sytuacji finansowej. Rodzina ze względu na wielość wymagań, jakie przed nią stawia społeczeństwo, naród i społeczność lokalna, ma do spełnienia wiele funkcji. Funkcje rodziny to cele, do których zmierza życie i działalność rodzinna, oraz zadania, które pełni, zaspokajając potrzeby swych członków i całego 
społeczeństwa ${ }^{19}$. Pojawienie się $\mathrm{w}$ rodzinie dziecka z niepełnosprawnością powoduje pojawienie się wielu nowych potrzeb związanych $\mathrm{z}$ codziennym funkcjonowaniem. Oczywiste są zmiany w funkcjonowaniu rodziny, zmiany w relacjach pomiędzy małżonkami czy często występujące ograniczenie kontaktów towarzyskich ${ }^{20}$. Niewątpliwie ta nowa, trudna sytuacja wymusza wiele, często diametralnych zmian w funkcjonowaniu rodziny. Zmianom ulegają dotychczasowe plany życiowe, rodzice stają przed koniecznością zreorganizowania swojego życia, zmian ról społecznych, które do tej pory pełnili, rozwiązywania nowych problemów. Ważnym elementem systemu wsparcia, który winien być wykorzystywany w pierwszych dniach, tygodniach, miesiącach czasem latach życia dziecka, jest wczesne wspomaganie rozwoju dziecka ${ }^{21}$.

Możliwość organizowania w systemie oświaty działań stymulujących rozwój małego dziecka od chwili wykrycia niepełnosprawności do rozpoczęcia nauki w szkole wprowadzona została w roku 2005. Zespoły wczesnego wspomagania rozwoju dziecka w celu pobudzania jego psychoruchowego i społecznego rozwoju mogą być tworzone ${ }^{22}$ w przedszkolach i szkołach podstawowych, w tym specjalnych, w ośrodkach szkolno-wychowawczych, specjalnych ośrodkach wychowawczych, ośrodkach rewalidacyjno-wychowawczych oraz w publicznych i niepublicznych poradniach psychologiczno-pedagogicznych, w tym poradniach specjalistycznych. Wczesne wspomaganie rozwoju

19 Por. F. Adamski, Socjologia matżeństwa i rodziny, Warszawa 1982, s. 46.

20 Por. M. Kościółek, Lęk rodziców wychowujących dziecko z niepetnosprawnościa, dz. cyt., s. 75-81.

21 Opracowano na podstawie Informacji Rządu Rzeczypospolitej Polskiej o działaniach podejmowanych w 2012 roku na rzecz realizacji postanowień uchwały Sejmu Rzeczypospolitej Polskiej z dnia 1 sierpnia 1997 r. Karta Praw Osób Niepełnosprawnych.

22 Na podstawie art. 71 ust. 2a ustawy z dnia 7 września 1991 r. o systemie oświaty (Dz.U. z 1991 r. Nr 95, poz. 425). 
organizuje $\operatorname{się}^{23}$ na podstawie opinii wydanej przez zespół orzekający publicznej poradni psychologiczno-pedagogicznej, w tym specjalistycznej ${ }^{24}$ lub zespół opiniujący powołany $\mathrm{w}$ niepublicznej poradni psychologiczno-pedagogicznej, założonej zgodnie z art. 82 ustawy o systemie oświaty oraz zatrudniającej pracowników posiadających kwalifikacje określone dla pracowników publicznych poradni psychologiczno-pedagogicznych. Na realizację m.in. wczesnego wspomagania rozwoju dzieci, przekazywane są środki finansowe z budżetu państwa w ramach części oświatowej subwencji ogólnej, na podstawie opinii o potrzebie wczesnego wspomagania rozwoju, wydanej przez publiczną bądź niepubliczną poradnię psychologiczno-pedagogiczną.

\section{Edukacja dzieci i młodzieży $\mathrm{z}$ niepełnosprawnościami ${ }^{25}$}

Wraz z rozwojem dziecka i osiągnięciem przez niego wieku szkolnego przed rodziną pojawiają się kolejne wyzwania związane z realizacją obowiązku szkolnego. Preambuła ustawy o systemie oświaty ${ }^{26}$ mówi dobitnie, iż „szkoła

23 Organizację pracy zespołów wczesnego wspomagania rozwoju dziecka określa rozporządzenie Ministra Edukacji Narodowej z dnia 3 lutego 2009 r. w sprawie organizowania wczesnego wspomagania rozwoju dzieci (Dz.U. Nr 23, poz. 133).

24 Na podstawie przepisów rozporządzenia Ministra Edukacji Narodowej z dnia 18 września 2008 r. w sprawie orzeczeń i opinii wydawanych przez zespoły orzekające działające w publicznych poradniach psychologiczno-pedagogicznych (Dz.U. Nr 173, poz. 1072).

25 Kwestie związane $\mathrm{z}$ organizacją kształcenia specjalnego reguluje art. 71b ustawy z dnia 7 września 1991 r. o systemie oświaty (Dz.U. z 2004 r. Nr 256, poz. 2572, z późn. zm.) oraz rozporządzenia wykonawcze do ustawy.

26 Ustawa z dnia 7 września 1991 r. o systemie oświaty (Dz.U. z 1991 r. Nr 95, poz. 425). 
winna zapewnić każdemu uczniowi warunki niezbędne do jego rozwoju, przygotować go do wypełniania obowiązków rodzinnych i obywatelskich w oparciu o zasady solidarności, demokracji, tolerancji, sprawiedliwości i wolności". Z kolei artykuł 1 tej ustawy zawiera szereg istotnych gwarancji:

„System oświaty zapewnia w szczególności:

1) realizację prawa każdego obywatela Rzeczypospolitej Polskiej do kształcenia się oraz prawa dzieci i młodzieży do wychowania i opieki, odpowiednich do wieku i osiągniętego rozwoju;

2) wspomaganie przez szkołę wychowawczej roli rodziny; $[\ldots]$

3) dostosowanie treści, metod i organizacji nauczania do możliwości psychofizycznych uczniów, a także możliwość korzystania z pomocy psychologiczno-pedagogicznej i specjalnych form pracy dydaktycznej;

4) możliwość pobierania nauki we wszystkich typach szkół przez dzieci i młodzież niepełnosprawną oraz niedostosowaną społecznie, zgodnie z indywidualnymi potrzebami rozwojowymi i edukacyjnymi oraz predyspozycjami;

5) opiekę nad uczniami niepełnosprawnymi przez umożliwianie realizowania zindywidualizowanego procesu kształcenia, form i programów nauczania oraz zajęć rewalidacyjnych; [...]

6) upowszechnianie dostępu do szkól, których ukończenie umożliwia dalsze kształcenie w szkołach wyższych [...] ${ }^{27}$.

W zależności od rodzaju niepełnosprawności ${ }^{28}$, w tym stopnia niepełnosprawności intelektualnej, dzieciom i młodzieży niepełnosprawnym organizuje się kształcenie i wychowanie, które stosownie do potrzeb umożliwia naukę w dostępnym dla nich zakresie, usprawnianie zaburzonych

\footnotetext{
27 Tamże.

28 Zgodnie z art. 71b ust. 2 ustawy o systemie oświaty (Dz.U. z $1991 \mathrm{r}$. Nr 95, poz. 425).
} 
funkcji, rewalidację oraz zapewnia specjalistyczną pomoc i opiekę. Oznacza to, że uczniowie niepełnosprawni, niezależnie od miejsca kształcenia, mają prawo do kształcenia specjalnego dostosowanego do ich indywidualnych potrzeb rozwojowych i edukacyjnych oraz możliwości psychicznych. Uczniowie niepełnosprawni mogą się uczyć w każdym typie i rodzaju szkoły. Wybór miejsca kształcenia należy do rodziców (opiekunów prawnych) dziecka.

Dla dzieci i młodzieży, które z powodu niepełnosprawności nie mogą uczęszczać do szkoły w miejscu zamieszkania prowadzone są specjalne ośrodki szkolno-wychowaw$\mathrm{cze}^{29}$, w których ci uczniowie mogą spełniać obowiązek szkolny i obowiązek nauki, mają zapewnioną całodobową opiekę pedagogiczną, oraz specjalne ośrodki wychowawcze, zapewniające im wychowanie i opiekę.

Kolejnym elementem systemu wsparcia osób niepełnosprawnych są organizacje pozarządowe, grupy samopomocy i wolontariusze, stosunkowo nowy element struktur społecznych, stanowiące wtórny system świadczeń wypełnianych w bezpośrednich kontaktach. Mogą to być stowarzyszenia osób chorych i ich rodzin albo stowarzyszenia typu hospicyjnego, pomoc i wsparcie przyjaciół, znajomych, sąsiadów bądź ludzi, którzy mają za sobą podobne problemy i wiedzą już nie tylko, jak sobie z nimi radzić, ale także jak ważna jest pomoc, porada i obecność innych osób ${ }^{30}$. Wielokrotnie to właśnie organizacje pozarządowe - fundacje i stowarzyszenia są realizatorami zadań zlecanych przez samorządy, które dotyczą udzielania wsparcia osobom z niepełnosprawnościami

29 Zgodnie z przepisami rozporządzenia Ministra Edukacji Narodowej z dnia 12 maja 2011 r. w sprawie rodzajów i szczegółowych zasad działania placówek publicznych, warunków pobytu dzieci i młodzieży w tych placówkach oraz wysokości i zasad odpłatności wnoszonej przez rodziców za pobyt ich dzieci w tych placówkach (Dz.U. Nr 109, poz. 631).

30 Por. L. Marszałek, Systemy wsparcia społecznego w procesie rehabilitacji osób niepetnosprawnych, „Seminare” 2009 t. 26, s. 201-213. 
i ich rodzinom poprzez organizowanie i prowadzenie placówek wsparcia dziennego, całodobowego, punktów poradnictwa specjalistycznego czy innych niezbędnych do codziennego funkcjonowania form wsparcia.

Jedną z form aktywności wspomagającej proces rehabilitacji społecznej i zawodowej osób niepełnosprawnych prowadzonej przez organizacje pozarządowe są warsztaty terapii zajęciowej. Warsztaty te, będące placówką dziennego pobytu, przeznaczone są dla osób niepełnosprawnych niezdolnych do podjęcia pracy, a ich podstawową działalnością terapeutyczną jest - zgodnie z ustawą ${ }^{31}$ - pozyskiwanie lub przywracanie osobom niepełnosprawnym umiejętności niezbędnych do podjęcia zatrudnienia i kontynuowanie rehabilitacji zawodowej w warunkach pracy chronionej lub na przystosowanym stanowisku pracy. Zajęcia są prowadzone $\mathrm{w}$ pracowniach terapeutycznych, zgodnie $\mathrm{z}$ indywidualnym programem przygotowanym dla uczestników przez radę programową warsztatu, w formie różnorodnych technik terapii zajęciowej. Podstawowym celem zajęć terapeutycznych jest usamodzielnienie osób niepełnosprawnych, czyli nabycie przez nich podstawowych umiejętności wykonywania czynności życia codziennego i zaradności osobistej oraz rozwijania psychofizycznych sprawności, a także podstawowych i specjalistycznych umiejętności zawodowych, umożliwiających uczestnictwo $\mathrm{w}$ szkoleniu zawodowym albo podjęcie pracy w warunkach chronionych. Warsztaty terapii zajęciowej - prowadzone przez organizacje pozarządowe, zakłady pracy chronionej lub inne jednostki

31 Ustawa z dnia 27 sierpnia 1997 r. o rehabilitacji zawodowej i społecznej oraz zatrudnianiu osób niepełnosprawnych (Dz.U. $2011 \mathrm{r}$. Nr 127, poz. 721, z późn. zm.). Przy czym warto podkreślić, że rehabilitacja została zdefiniowana jako „zespół działań, w szczególności organizacyjnych, leczniczych, psychologicznych, technicznych, szkoleniowych, edukacyjnych i społecznych, zmierzających do osiągnięcia, przy aktywnym uczestnictwie tych osób, możliwie najwyższego poziomu ich funkcjonowania, jakości życia i integracji społecznej”. 
organizacyjne - nie są przedsięwzięciem zarobkowym, a ewentualny dochód ze sprzedaży produktów i usług wytworzonych i wykonywanych w ramach realizowanego programu terapii, przeznaczają na wzbogacenie ustawowej działalności.

Warsztaty terapii zajęciowej dofinansowywane są przez samorządy powiatowe, ze środków własnych i Państwowego Funduszu Rehabilitacji Osób Niepełnosprawnych.

Podsumowując omówione powyżej elementy systemu wsparcia, warto zwrócić uwagę na profesjonalistów, którzy wypełniając znaczące role społeczne, wpływają na sytuację biopsychospołeczną osób z niepełnosprawnościami i ich rodzin:

\section{a) Pracownik socjalny}

"Głównym zadaniem pracownika socjalnego jest pomoc i wsparcie osób zmarginalizowanych. Powinien on mobilizować swoich klientów do przezwyciężania sytuacji trudnych, do określonych zmian w ich życiu. [...] Praca socjalna z rodziną powinna sprowadzać się do:

- „pedagogizacji rodziców” - od uczenia, jak robi się zakupy i pranie, rozpoznaje choroby dziecięce, pielęgnuje niemowlę, przez inicjowanie kontaktów ze szkołą, przygotowywanie dzieci do zajęć szkolnych, do poradnictwa rodzinnego w zakresie konfliktów w rodzinie, przeciwdziałania przemocy i unikanie uzależnień,

- pomocy w kontaktowaniu się z urzędami, kompletowanie dokumentów niezbędnych przy niektórych procedurach, np. występowaniu o orzeczenie do Zespołu Orzekania o Stopniu Niepełnosprawności, ZUS-u,

- kierowaniu na kursy zawodowe, terapie specjalistyczne, do grup samopomocy,

- pośrednictwie w zdobywaniu sprzętu domowego, przeprowadzaniu remontów i modernizacji mieszkań,

- aktywizowaniu liderów lokalnych do wspierania konkretnych środowisk, 
- poszukiwaniu pomocy w ofercie organizacji pozarządowych - organizowaniu wypoczynku dla dzieci, pomoc przedświąteczna, wspieranie rozwoju dzieci przez zajęcia w świetlicach terapeutycznych, pomocy w opiece nad dziećmi niepełnosprawnymi,

- nawiązywaniu kontaktów z dalszą rodziną w celu wspólnego przezwyciężania trudnej sytuacji rodziny,

- aktywizowaniu lekarza pierwszego kontaktu lub pielęgniarki pracującej w szkole do bacznego monitorowania sytuacji zdrowotnej dzieci,

- kierowaniu dzieci do świetlicy środowiskowej (względnie organizowanie tej formy wspierania)"32.

\section{b) Psycholog}

Zadaniem psychologa jest:

- dokonanie oceny rozwoju psychicznego dziecka, tzn. jego możliwości intelektualnych, stanu emocjonalnego i społecznego,

- wsparcie emocjonalne rodziny osoby z niepełnosprawnością,

- wsparcie w rozwiązywaniu codziennych problemów, $\mathrm{z}$ jakimi się

- rodzice niepełnosprawnych dzieci stykają się na co dzień - np.: jak zawiadomić rodzeństwo o niepełnosprawności siostry lub brata, jak zaakceptować niepełnosprawność dziecka.

\section{c) Lekarz}

- wyjaśni, co oznacza diagnoza i czym rozpoznanie może skutkować w przyszłym życiu dziecka;

32 M. Porąbaniec, Działania pracowników socjalnych podejmowane na rzecz zapobiegania zjawisku wykluczenia społecznego dzieci i mtodzieży z rodzin dysfunkcyjnych, „Pedagogika Rodziny. Family Pedagogy" 2011 nr 1 (1), s. 92-93. 
- w razie potrzeby wprowadzi leczenie farmakologiczne, zadecyduje o przeprowadzeniu odpowiednich badań.

\section{d) Fizjoterapeuta}

- oceni poziom rozwoju ruchowego dziecka, nauczy podstawowych ćwiczeń i zabiegów,

- podpowie, jak wpleść rehabilitację w czynności dnia codziennego lub w zabawę,

- pokaże, w jakiej pozycji ułożeniowej powinno przebywać dziecko, jaki sprzęt rehabilitacyjny jest dla dziecka niezbędny.

\section{e) Logopeda}

- oceni poziom rozwoju mowy,

- podpowie, w jaki sposób karmić dziecko, jak ćwiczyć narządy artykulacyjne,

- pomoże w wyborze najlepszej metody porozumiewania się z dzieckiem.

\section{f) Pedagog}

- nauczy, jak stymulować rozwój dziecka, w jaki sposób bawić się z nim, wykorzystując odpowiednie zabawki i pomoce,

- podpowie, jak prowadzić trening samoobsługi,

- pokaże ćwiczenia wspomagające rozwój umiejętności czytania, pisania i liczenia ${ }^{33}$.

\section{Podsumowanie}

W codziennym funkcjonowaniu osoby z niepełnosprawnością i jej rodziny niezbędne jest sprawne funkcjonowanie

33 Podpunkty od b) do f) por. Twoje dziecko jest inne. Informacje i porady praktyczne dla rodziców dzieci zagrożonych niepetnosprawnościa lub dzieci z niepetnosprawnościq intelektualna w wieku 0-7 lat, red. B. Abramowska, Warszawa 2008, s. 8. 
systemu wsparcia. Systemu, którego elementy będą odpowiadały potrzebom odbiorców. Wspieranie rodziny obejmuje działania, których celem jest pomoc w przezwyciężeniu problemów oraz trudności naruszających jej poprawne funkcjonowanie materialne, kulturowe, wychowawcze, emocjonalne i społeczne ${ }^{34}$. Każdy element systemu wsparcia jest równie ważny - każda z osoba z niepełnosprawnością ma inne potrzeby, inne możliwości i oczekiwania. Profesjonaliści pełnią w systemie wsparcia kluczową rolę - od ich profesjonalizmu, wysokiego poziomu wiedzy, umiejętności komunikacji i okazywanej empatii zależy poziom jakości życia osób z niepełnosprawnościami, ich rodzin, wreszcie całego społeczeństwa.

\section{Bibliografia}

Adamski F., Socjologia małżeństwa i rodziny, Warszawa 1982.

Dane statystyczne dotyczące sytuacji osób niepełnosprawnych z uwzględnieniem istotnych zmian i tendencji na przestrzeni ostatnich lat, http://www.niepelnosprawni.gov.pl/download/ (15iane7hW5Wxx6KZcIDWz5Wzip-nj9GhbI-XntyyU6Dfjpiin5iZnuayV5mwdtvgqtPHxt3ZgNTpw8rGpMfL09jkj9TpxNrIrczfxtvXj8bVxNrhm9Ha1e3dj87Vw9vbl9LUzNbggNHXyJbLpcGInvA)/files/niepelnosprawnosc_w_liczbach/rynek_pracy/ sytuacja_osob_niepelnosprawnych_na_przestrzeni_ostatnich_ lat.doc. (15.10.2014).

Główny Urząd Statystyczny, Raport z wyników. Narodowy Spis Ludności i Mieszkań 2011, Warszawa 2012.

Informacje Rządu Rzeczypospolitej Polskiej o działaniach podejmowanych w 2012 roku na rzecz realizacji postanowień uchwały Sejmu Rzeczypospolitej Polskiej z dnia 1 sierpnia 1997 r. Karta Praw Osób Niepełnosprawnych.

34 Por. I. Izdebska, Dziecko w rodzinie u progu XXI wieku, Białystok 2000, s. 100. 
Izdebska I., Dziecko w rodzinie u progu XXI wieku, Białystok 2000. Janocha W., Rodzina z osobq niepetnosprawna w społecznym systemie wsparcia, Kielce 2009.

Kawczyńska-Butrym Z., Elementy socjologii dla pielęgniarek, Lublin 2000.

Kościółek M., Lęk rodziców wychowujących dziecko z niepełnosprawnością, [w:] Dziecko a świat dorostych, red. M. Duda, B. Gulla, Kraków 2007, s. 75-81.

Maciarz A., Wspomaganie rodziny w wychowaniu i rehabilitacji dzieci, „Problemy Opiekuńczo-Wychowawcze” 1992 nr 5/6, s. 254-257.

Marszałek L., Systemy wsparcia społecznego w procesie rehabilitacji osób niepetnosprawnych, „Seminare” 2009 t. 26, s. 201-213.

Mellibruda J., Ja - ty - my. Psychologiczne możliwości ulepszania kontaktów międzyludzkich, Warszawa 1986.

Porąbaniec M., Działania pracowników socjalnych podejmowane na rzecz zapobiegania zjawisku wykluczenia spotecznego dzieci $i$ młodzieży z rodzin dysfunkcyjnych, „Pedagogika Rodziny. Family Pedagogy", 2011 nr 1 (1), s. 83-95.

Radochoński M., Rola rodziny w zmaganiu się ze stresem wywotanym choroba somatyczna, „Problemy Rodziny” 1991 nr 6, s. 6-10.

www.stat.gov.pl (21.10.2014)

\section{Akty prawne}

Ustawa z dnia 27 sierpnia 1997 r. o rehabilitacji zawodowej i społecznej oraz zatrudnianiu osób niepełnosprawnych (Dz.U. z 1997 r. Nr 123, poz. 776, art. 6b; Dz.U. z 2011 r. Nr 127, poz. $721, \mathrm{z}$ późn. zm.).

Prawo o ruchu drogowym (Dz.U. z 2012 r., poz. 1137, z późn. zm. 4). Rozporządzenie Ministra Zdrowia z dnia 6 grudnia 2013 r. w sprawie wykazu wyrobów medycznych wydawanych na zlecenie (Dz.U. z 2013 r. poz. 1565).

Ustawa o świadczeniach rodzinnych (Dz.U. z 2006 r. Nr 139, poz. 992, z późn. zm.).

Ustawa o systemie oświaty, z dnia 7 września 1991 r. (Dz.U. z 2004 r. Nr 256, poz. 2572, z późn. zm.). 
Rozporządzenie Ministra Edukacji Narodowej z dnia 3 lutego 2009 r. $\mathrm{w}$ sprawie organizowania wczesnego wspomagania rozwoju dzieci (Dz.U. Nr 23, poz. 133).

Rozporządzenie Ministra Edukacji Narodowej z dnia 18 września 2008 r. w sprawie orzeczeń i opinii wydawanych przez zespoły orzekające działające w publicznych poradniach psychologiczno-pedagogicznych (Dz.U. Nr 173, poz. 1072).

Rozporządzenie Ministra Edukacji Narodowej z dnia 12 maja 2011 r. w sprawie rodzajów i szczegółowych zasad działania placówek publicznych, warunków pobytu dzieci i młodzieży w tych placówkach oraz wysokości i zasad odpłatności wnoszonej przez rodziców za pobyt ich dzieci w tych placówkach (Dz.U. Nr 109, poz. 631).

\section{Streszczenie}

Sytuacja pojawienia się osoby z niepełnosprawnością w rodzinie stawia przed wszystkimi jej członkami nowe zadania. W związku z pojawieniem się nowych obowiązków - pielęgnacyjnych, rehabilitacyjnych czy edukacyjnych w odniesieniu do osoby niepełnosprawnej, zmianie ulegają relacje wewnątrzrodzinne, sytuacja finansowa czy organizacyjna rodziny. Konieczne jest zapoznanie się z istniejącym w Polsce systemem wsparcia, tak aby stworzyć osobie niepełnosprawnej jak najlepsze warunki rozwoju biopsychospołecznego i wysokiej jakości życia. W artykule zaprezentowano funkcjonujący w Polsce system wsparcia osób z niepełnosprawnościami i ich rodzin, z uwzględnieniem obowiązujących przepisów prawnych i wskazania instytucji, w kompetencji których znajdują się zadania związane z udzielaniem wsparcia.

Słowa kluczowe: niepełnosprawność, edukacja, system wsparcia, rodzina 


\section{Summary}

\section{Support system for people with disabilities and their families in Poland}

Whenever person with disabilities becomes a part of the family it creates new challenges for everyone involved. From that moment things like care, rehabilitation or education start to change relations between family members, financial situation or potential planing. It's imperative to learn about Polish support system in order to create right environment for development and high standard of life.

The article shows examples of Polish support system for those people and their loved ones, current laws and institutions charged with providing necessary help in that circumstances.

Keywords: disability, education, suport system, family

Katarzyna Kutek-Sładek, System wsparcia osób z niepetnosprawnościami i ich rodzin w Polsce, [w:] Pedagogiczne konteksty społecznego wsparcia rodziny, red. ks. Grzegorz Godawa, Kraków 2015, s. 179-205. 